\title{
A NOVEL PROTEIN KINASE C INHIBITOR IN BOVINE SPERMATOZOA AND ITS EFFECTS ON THE DEVELOPMENT OF FERTILIZED OVA
}

\author{
Bingzhi Yu ${ }^{1,2}$, Hainui Xue ${ }^{1}$, Yu Yang ${ }^{1}$, Tiejun Zhao ${ }^{1}$ and Zhinong Zong ${ }^{1}$ \\ ${ }^{1}$ Department of Biochemistry, China Medical University, Shenyang, Liaoning 110001, China
}

\begin{abstract}
We found a protein kinase $\mathrm{C}$ (PKC) inhibitor in bovine spermatozoa. The inhibitor was purified by Sephadex G-200 gel filtration chromatography, isoelectric focusing and Mono Q chromatography. Inhibition of the PKC activity observed with $2 \mu \mathrm{g}$ of the purified inhibitor was comparable with that with $5 \mu \mathrm{mol}$ of chlorpromazine, a known potent inhibitor of PKC. Molecular weight of this inhibitor was estimated to be about 63,000 , and isoelectric point was $\mathrm{pH}$ 4.5. The inhibitor was inactivated when boiled, or digested with trypsin, whereas DNase and RNase were without effect, indicating that the inhibitor is a protein. The inhibitor is neither a protease nor a phosphatase. In fresh bovine spermatozoa, the PKC activity was almost undetectable probably because of the presence of the PKC inhibitor. When spermatozoa were incubated at $\mathrm{pH} 7.5$ at $37^{\circ} \mathrm{C}$ for $12-16 \mathrm{~h}$, more than half the activity of $\mathrm{PKC}$ inhibitor was lost, suggesting that the inhibitor was inactivated by proteolysis. When the purified inhibitor was microinjected into mouse fertilized ova, both the development of onecell fertilized ova into two-cell stage ova, and two-cell late stage ova into four-cell stage ova were inhibited. In contrast, PKC microinjected into two-cell early stage ova promoted their development into the four-cell and eight-cell stages; two-cell early stage ova injected with saline remained in the same stage. The results suggest a regulatory role of PKC and the PKC inhibitor in the development of fertilized ova.
\end{abstract}

Protein kinase $\mathrm{C}$ (PKC) plays important roles in signal transduction and also in cell proliferation and carcinogenesis (21-24). Although calcium in cytoplasm has been known to function in the development of fertilized ova (19), no direct evidence has been presented that PKC is involved in this process. The assay of PKC has generally been carried out with histone as substrate in the presence of $\mathrm{Ca}^{2+}$, phosphatidylserine, and diacylglycerol (15). In contrast, assay of PKC needs neither $\mathrm{Ca}^{2+}$, phosphatidylserine, nor diacylglycerol, when protamine was used as substrate; $\mathrm{Ca}^{2+}$ rather inhibited the PKC activity (39).

\footnotetext{
${ }^{2}$ To whom correspondence should be addressed Abbreviations: $\mathrm{PKC}$, protein kinase C; PMSG, pregnant mare serum gonadotropin; HCG, human chorionic gonadotropin
}

Protamine is found only in mature spermatozoa. Does PKC exist in spermatozoa? We tried to extract $\mathrm{PKC}$ from bovine and human sperm and to measure its activity. However, PKC activity in spermatozoan extracts has been difficult to measure, in accordance with previous reports indicating the absense of PKC in ram spermatozoa (30) or its low level in human spermatozoa (31). However, we noticed that the activity of PKC purified from rat brain was inhibited by adding spermatozoan extract, suggesting the presence of a PKC inhibitor in spermatozoa (unpublished).

PKC inhibitors reported so far in literature include 1) synthetic compounds such as chlorpromazine (20), trifluoperazine (32), tamoxifen (26), aminoacridines (5), isoquinolinesulfonamides (6, $8,27)$, and various synthetic peptides $(7,9,10,35)$; and 2) inhibitors of biological origin such as adria- 
mycin (37), sphingosine (6), sangivamycin (16), concanavalin A (28), defensins (3) and staurosporine $(36,38)$. Besides these, endogenous PKC inhibitors have been found in normal mammalian tissues. Schwantke and Le Peuce isolated a $20 \mathrm{kDa}$ PKC inhibitor from rat brain (33), and McDonald and Walsh isolated from bovine brain a $17 \mathrm{kDa}$ PKC inhibitor protein which has some resemblance to calmodulin (18). Hucho et al. (11) isolated from bovine brain cytosol a $40 \mathrm{kDa}$ heat-stable protein with $\mathrm{PKC}$-inhibiting activity. Balazovich et al. (1) suggested the presence of another type of PKC inhibitor protein which is associated with neutrophil-specific granule membrane.

We have isolated and characterized a novel PKC inhibitor from bovine spermatozoa, and demonstrated that the inhibitor exerts an inhibitory action on the development of fertilized ova.

\section{MATERIALS AND METHODS}

\section{Materials}

PKC was purified from rat brain soluble fraction as described by Inoue et al. (12). Diacylglycerol, III-S histone, Ampholine and chemicals used in Whitten culture medium (glucose, crystalline BSA, polyvinylpyrrolidone, and EDTA) were purchased from Sigma (St. Louis, MO, U.S.A.). Animals (6-week-old female and 8-week-old male Kumning mice) were supplied from the Department of Laboratory Animals, China Medical University. Fresh bovine spermatozoa were obtained at a local slaughterhouse and transported to our laboratory packed in ice. Pregnant mare serum gonadotropin (PMSG) and human chorionic gonadotropin (HCG) were obtained from the Changchun Biological Products Research Institute (Changchun, Jilin, China) and the Shanghai Biological Products Research Institute (Shanghai, China), respectively.

\section{Determination of the PKC Activity}

PKC activity was determined by the method of Kikkawa et al. (15) by measuring the incorporation of ${ }^{32} \mathrm{P}$ from $\left[\gamma{ }^{32} \mathrm{P}\right]$ ATP into III-S histone. Reaction mixture $(0.14 \mathrm{ml})$ contained $5 \mu \mathrm{mol}$ of Tris $/ \mathrm{HCl}$ (pH 7.5), $1.25 \mu \mathrm{mol}$ of $\mathrm{Mg}$ acetate, $50 \mu \mathrm{g}$ of III-S histone, $2.5 \mathrm{nmol}$ of $\left[\gamma{ }^{32} \mathrm{P}\right] \mathrm{ATP}\left(15-20 \times 10^{6} \mathrm{cpm} /\right.$ nmol), $125 \mathrm{nmol}$ of $\mathrm{CaCl}_{2}, 10 \mu \mathrm{g}$ of phosphatidylserine, and $0.4 \mu \mathrm{g}$ of diacylglycerol. The reaction was started by the addition of reaction mixture to tubes containing $90 \mu \mathrm{l}$ distilled water and $20 \mu \mathrm{l} \mathrm{PKC}$ to be assayed, and terminated after incubation for $3 \mathrm{~min}$ at $30^{\circ} \mathrm{C}$ by adding $3 \mathrm{ml}$ of $25 \%$ trichloroacetic acid. Acid-precipitated materials were collected on a Toyo Roshi membrane filter (pore size, $0.45 \mu \mathrm{m}$ ), and radioactivity was counted in a scintillation counter.

\section{Determination of the Inhibitor Activity}

Activity of purified rat brain PKC $(0.4 \mu \mathrm{g})$ was measured in the presence and absence of appropriate amount of PKC inhibitor. Inhibitor activity was expressed as a percentage decrease, taking the PKC activity in the absence of inhibitor as $100 \%$. One unit of PKC inhibitor was defined as the activity which causes $50 \%$ inhibition of the PKC activity.

\section{Microinjection of PKC and PKC Inhibitor into Fertilized Ova}

Micropipets were prepared from glass capillaries (outer diameter $2 \mathrm{~mm}$ ) using a micropipet puller (W-P Instruments, New Haven, CT, U.S.A.). Diameter of the micropipet tip was $0.5-1.0 \mu \mathrm{m}$. Solutions were delivered into the micropipet through its rear open end by means of a 20 gauge Angiocath (Deseret, Sandy, UT, U.S.A.), and microinjected into fertilized ova by using a micromanipulator (MP-1, Narishige, Tokyo, Japan) under an inverted microscope (TMS, Nikon, Tokyo, Japan). Temperature was maintained at $37^{\circ} \mathrm{C}$ using a plastic housing equipped with an incubator. The volume of injected solution was approximately $2 \mathrm{pl}$. When the microinjection caused cell damages such as bleb formation, these ova were excluded.

\section{Culture of Fertilized Ova}

Ova were transferred to the Whitten culture medium, pre-equilibrated at $37^{\circ} \mathrm{C}$ and in $5 \% \mathrm{CO}_{2} / 95 \%$ $\mathrm{O}_{2}$. The Whitten culture medium contained

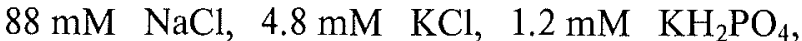
$1.2 \mathrm{mM} \mathrm{MgSO}_{4} \cdot 7 \mathrm{H}_{2} \mathrm{O}, 23 \mathrm{mM} \mathrm{NaHCO} 3,5.5 \mathrm{mM}$ glucose, $1.7 \mathrm{mM}$ Ca lactate, $50 \mathrm{mM} \mathrm{Na}$ lactate, $0.23 \mathrm{mM}$ Na pyruvate, $0.1 \mathrm{mM}$ EDTA, $1 \mathrm{mg} / \mathrm{ml}$ polyvinylpyrrolidone and $3 \mathrm{mg} / \mathrm{ml} \mathrm{BSA}$. The ova were incubated in a Queue cell culture incubator (Box 1901, Parksersburg, WV, U.S.A.).

\section{Other Methods}

Protein was determined by the method of Lowry et al. (17). Polyacrylamide gel electrophoresis was car- 


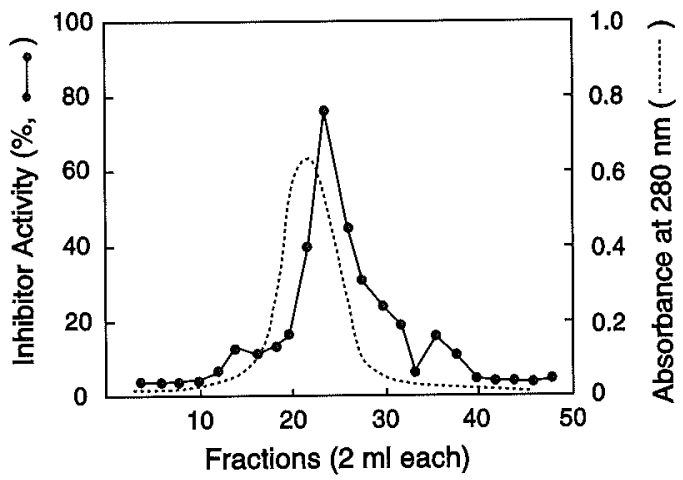

Fig. 1 Sephadex G-200 column chromatography of a $\mathrm{PKC}$ inhibitor protein. The PKC inhibitor activity was determined as described under 'Materials and Methods' with $10 \mu \mathrm{g}$ of purified rat brain PKC and $40 \mu \mathrm{l}$ each of eluate fractions from the Sephadex column. The inhibitor activity was represented as percentage decrease in the PKC activity. - , inhibitor activity; $\cdots .$. , absorbance at $280 \mathrm{~nm}$

ried out at $400 \mathrm{~V}$ for $4 \mathrm{~h}$. Samples were dissloved in $0.5 \mathrm{M}$ Tris/ $\mathrm{HCl}$ (pH 6.8) containing $2 \mathrm{M}$ glycerol and $0.7 \mathrm{M}$ 2-mercaptoethanol and subjected to electrophoresis. The separating gel consisted of an increasing gradient of polyacrylamide from 5 to $18 \%$. Proteins were stained with Coomassie Brilliant Blue. BSA $(68 \mathrm{kDa})$, ovalbumin $(45 \mathrm{kDa})$, pepsin $(34.7 \mathrm{kDa})$ and trypsin $(23.8 \mathrm{kDa})$ were used as molecular weight markers.

\section{RESULTS}

\section{Purification of a PKC Inhibitor from Bovine Spermatozoa}

All procedures were carried out at $0-4^{\circ} \mathrm{C}$. Fresh bovine spermatozoa $(2 \mathrm{ml})$ were mixed with $2 \mathrm{ml}$ of $20 \mathrm{mM}$ Tris/ $\mathrm{HCl}$ (pH 7.5) containing $0.25 \mathrm{M}$ sucrose, $10 \mathrm{mM}$ EGTA and $2 \mathrm{mM}$ EDTA, and centrifuged at 2,000 rpm for $10 \mathrm{~min}$. The supernatant was discarded. The same operation was repeated to remove impurities. The pellet was suspended in the same buffer $(2 \mathrm{ml})$, homogenized in a sonic dismembrator (Fisher Scientific, F50, Pittsbutgh, PA, U.S.A.) for $1 \mathrm{~min}$. After centrifugation at $100,000 \mathrm{~g}$ for $1 \mathrm{~h}, \mathrm{PKC}$ inhibitor activity was largely recovered in the soluble fraction. The activity detected in the pellet was negligible, if at all. The soluble fraction $(2 \mathrm{ml}, 17.8 \mathrm{mg}$ protein) was applied to a Sephadex G-200 column $(1.5 \times 90 \mathrm{~cm})$ which had been equilibrated with $20 \mathrm{mM}$ Tris/ $\mathrm{HCl}(\mathrm{pH} 7.5)$ containing $10 \mathrm{mM}$ 2-mercaptoethanol, $0.5 \mathrm{mM}$

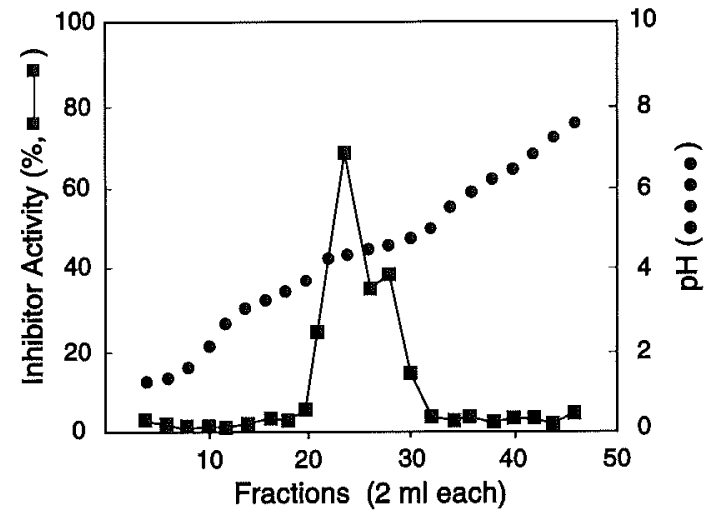

Fig. 2 Isoelectric focusing of the PKC inhibitor protein. Isoelectric focusing and determination of the PKC inhibitor activity were carried out as described in the text and in the legend to Fig. 1. ity; $\cdots \cdots, \mathrm{pH}$

EDTA and $0.5 \mathrm{mM}$ EGTA. Elution was carried out with the same buffer, and fractions of $2 \mathrm{ml}$ each were collected. The PKC inhibitor activity was detected in fractions 22-27 (Fig. 1). Active fractions (12 ml, $4.77 \mathrm{mg}$ protein) were combined and concentrated to $2 \mathrm{ml}$ using an Amicon ultrafiltration apparatus (M-52, Lexington, MA, U.S.A.) with a PM-10 filter. The concentrate was subjected to isoelectric focusing using a $110 \mathrm{ml}$ column (LKB) of carrier ampholyte ( $\mathrm{pH} 4-6.5)$ at a final concentration of $1.5 \%$. After electrophoresis at $600 \mathrm{~V}$ for $38 \mathrm{~h}$, fractions of $2 \mathrm{ml}$ each were collected. The PKC inhibitor activity was recovered in fractions 23-27 (Fig. 2). The $\mathrm{pH}$ of the peak fraction determined at $4^{\circ} \mathrm{C}$ was about 4.5 . Combined active fractions ( $10 \mathrm{ml}, 0.44 \mathrm{mg}$ protein) were concentrated to $1 \mathrm{ml}$ by ultrafiltration and applied to a Mono Q column (HR 5/5, Pharmacia) which had been equilibrated with $20 \mathrm{mM}$ Tris/ $\mathrm{HCl}(\mathrm{pH} 7.5)$ containing $0.25 \mathrm{M}$ sucrose, $1.2 \mathrm{mM}$ EGTA, $20 \mathrm{mM}$ 2-mercaptoethanol and $0.1 \mathrm{mM}$ phenylmethylsulfonyl fluoride. Elution was carried out with a linear gradient of $\mathrm{NaCl}(0.2-0.7 \mathrm{M})$ at a flow rate of $1 \mathrm{ml} /$ $\mathrm{min}$, and $1 \mathrm{ml}$-fractions were collected. The PKC inhibitor activity was recovered in $0.45-0.55 \mathrm{M}$ fractions of the $\mathrm{NaCl}$ gradient (Fig. 3). Active fractions ( $3 \mathrm{ml}, 0.065 \mathrm{mg}$ protein) were combined and dialyzed first against a large excess of $20 \mathrm{mM}$ Tris/ $\mathrm{HCl}(\mathrm{pH} 7.5)$ containing $10 \mathrm{mM}$ 2-mercaptoethanol, $0.5 \mathrm{mM}$ EGTA, $0.5 \mathrm{mM}$ EDTA and $20 \%$ sucrose, and then against $0.9 \% \mathrm{NaCl}$. The purified PKC inhibitor was concentrated to $2 \mathrm{ml}$ by ultrafiltration and used for subsequent studies. A typical 
Table 1 Purification of a PKC Inhibitor Protein from Bovine Spermatozoa

\begin{tabular}{lccccc}
\hline \multicolumn{1}{c}{ Steps } & $\begin{array}{c}\text { Total } \\
\text { protein } \\
\text { (mg) }\end{array}$ & $\begin{array}{c}\text { Total inhibitor } \\
\text { activity } \\
\text { (units) }\end{array}$ & $\begin{array}{c}\text { Specific } \\
\text { activity } \\
\text { (units/mg) }\end{array}$ & $\begin{array}{c}\text { Purification } \\
\text { (-fold) }\end{array}$ & $\begin{array}{c}\text { Yield } \\
(\%)\end{array}$ \\
\hline $\begin{array}{l}100,000 \mathrm{~g} \\
\text { supernatant }\end{array}$ & 17.80 & 540.91 & 30.4 & 1 & 100 \\
$\begin{array}{l}\text { Sephadex G-200 } \\
\text { chromatography }\end{array}$ & 4.77 & 366.45 & 76.8 & 2.5 & 67.7 \\
$\begin{array}{l}\text { Isoelectric } \\
\text { focusing }\end{array}$ & 0.44 & 280.94 & 638.5 & 21.0 & 51.9 \\
$\begin{array}{l}\text { Mono Q column } \\
\text { chromatography }\end{array}$ & 0.065 & 145.26 & $2,234.8$ & 73.5 & 26.9 \\
\hline
\end{tabular}

PKC inhibitor protein was purified from $2 \mathrm{ml}$ of bovine spermatozoa. Details of the purification and assay of the PKC inhibitor activity are described in the text and legend to Fig. 1.

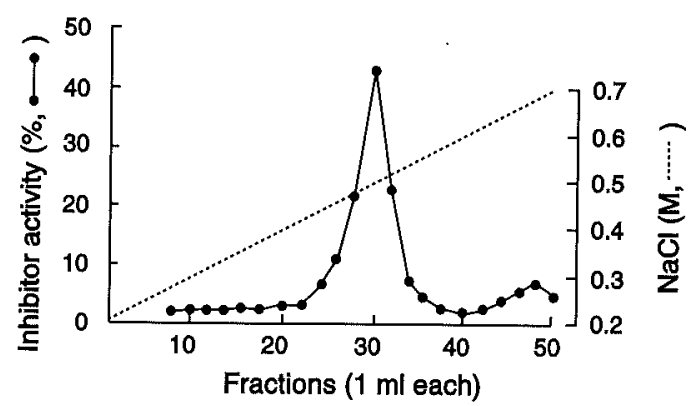

Fig. 3 Mono Q column chromatography of the PKC inhibitor protein. Chromatographic procedures and assay of the PKC inhibitor are as described in the text and legend to Fig. 1. $\longrightarrow$, inhibitor activity; $\cdots \cdots$, $\mathrm{NaCl}$ gradient

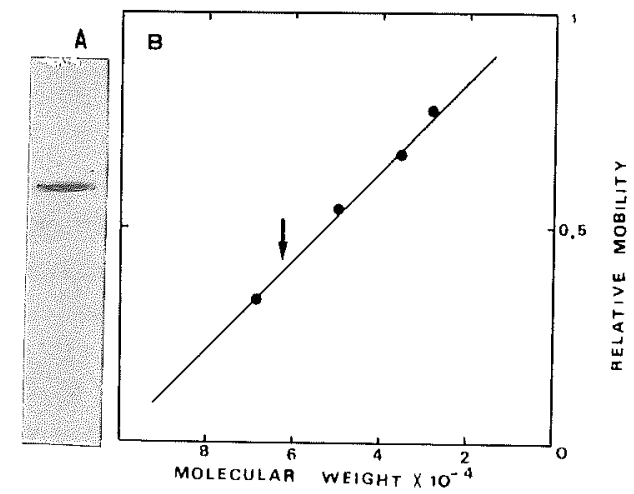

Fig. 4 Electrophoresis of the purified inhibitor. Polyacrylamide gel electrophoresis was carried out under conditions described in the text; $80 \mu \mathrm{g}$ of the protein were loaded (A). BSA $(68 \mathrm{kDa})$, ovalbumin $(45 \mathrm{kDa})$, pepsin $(34.7 \mathrm{kDa})$ and trypsin $(23.8 \mathrm{kDa})$ served as molecular weight markers (B)

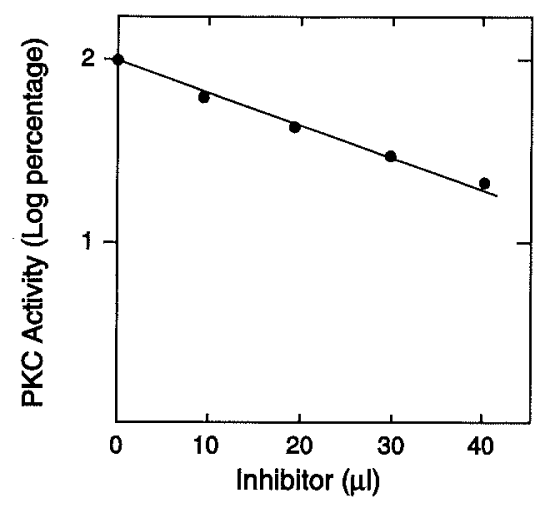

Fig. 5 Dose-dependent inhibition of PKC by the PKC inhibitor protein. The PKC activity in the presence of the inhibitor was expressed as logarithm of percent activity taking the activity in the absence of the inhibitor as $100 \%$. The PKC reaction with $0.4 \mu \mathrm{g}$ of purified rat brain PKC was carried out as described under 'Materials and Methods' in the presence of $0-40 \mu \mathrm{l}$ of the PKC inhibitor $(0.2 \mu \mathrm{g} / \mu \mathrm{l})$.

example of the purification procedure is presented in Table 1.

\section{Properties of the Purified PKC Inhibitor}

The purified PKC inhibitor gave apparently a single protein band, when $80 \mu \mathrm{g}$ protein was subjected to polyacrylamide gel electrophoresis (Fig. 4). The molecular weight was estimated to be about 63,000 .

Fig. 5 shows that the inhibition of PKC by the inhibitor was dose-dependent when PKC was assayed with III-S histone as substrate in the presence of $\mathrm{Ca}^{2+}$, phospholipid and diacylglycerol. The 
Table 2 Comparison of Inhibitory Effects of the PKC Inhibitor and Chlorpromazine

\begin{tabular}{lcc}
\hline & $\begin{array}{c}\text { Activity } \\
\text { (cpm) }\end{array}$ & $\begin{array}{c}\text { Inhibition } \\
(\%)\end{array}$ \\
\hline PKC & 15,000 & 0 \\
PKC + inhibitor & 7,000 & 46 \\
PKC + chlorpromazine & 6,000 & 60 \\
\hline
\end{tabular}

$\mathrm{PKC}$ reaction was carried out with $0.4 \mu \mathrm{g}$ of purified rat brain PKC as described under 'Materials and Methods'. Where indicated, $2 \mu \mathrm{g}$ of the purified bovine spermatozoa PKC inhibitor or $5 \mu \mathrm{mol}$ of chlorpromazine was included in the reaction mixture.

Table 3 Effects of Various Treatments of the PKC Inhibitor

\begin{tabular}{lc}
\hline \multicolumn{1}{c}{ Additions } & $\begin{array}{c}\text { Inhibition } \\
(\%)\end{array}$ \\
\hline None & 0 \\
PKCI & 48 \\
PKCI (boiled) & 1 \\
PKCI pretreated with trypsin & 8 \\
PKCI pretreated with DNase & \\
PKCI pretreated with RNase & 11 \\
\hline
\end{tabular}

$\mathrm{PKC}$ reaction was carried out with $0.4 \mu \mathrm{g}$ purified rat brain PKC, except that $10 \mu \mathrm{l}$ of the PKC inhibitor (PKCI) $(0.2 \mu \mathrm{g} / \mu \mathrm{l})$ were added after various treatments as indicated. Mean values of 3 to 5 experiments are shown. ${ }^{1}$ The PKC inhibitor was boiled for 3 min prior to the addition to the assay mixture. ${ }^{2}$ The PKC inhibitor had been treated with $0.2 \mathrm{mg} / \mathrm{ml}$ trypsin for $24 \mathrm{~h}$ at $30^{\circ} \mathrm{C}$. ${ }^{3,4}$ The PKC inhibitor had been treated with $300 \mu \mathrm{g} / \mathrm{ml}$ DNase or $100 \mu \mathrm{g} / \mathrm{ml}$ RNase for $6 \mathrm{~h}$ at $30^{\circ} \mathrm{C}$.

inhibition by $2 \mu \mathrm{g}$ of the inhibitor was comparable with that by $5 \mu \mathrm{mol}$ of chlorpromazine, a potent inhibitor of PKC (20), indicating that inhibitory effect of the bovine spermatozoa PKC inhibitor is very potent (Table 2). Table 3 shows effects of various treatments on the inhibitory activity of the PKC inhibitor. Trypsin digestion at $30^{\circ} \mathrm{C}$ for $24 \mathrm{~h}$, and boiling for 3 min caused a marked reduction in the inhibitory activity, whereas treatment with DNase or RNase was without effect. Activity of PKC could be altered by proteolysis of the enzyme, or by dephosphorylation of substrate protein of PKC, but inhibitory activity of the spermatozoan PKC inhibitor was not affected by protease inhibitors (phenylmethylsulfonyl fluoride and leupeptin) or by phosphatase inhibitors ( $\mathrm{NaF}$ and L-serine).
Table 4 Effects of Protease and Phosphatase Inhibitors

\begin{tabular}{lc}
\hline \multicolumn{1}{c}{ Additions } & $\begin{array}{c}\text { PKC inhibiting activity } \\
(\%)\end{array}$ \\
\hline None & 0 \\
PKCI & 44 \\
PKCI + NaF & 45 \\
PKCI + L-serine & 42 \\
PKCI + PMSF & 44 \\
PKCI + leupeptin & 46
\end{tabular}

PKC reaction with $0.4 \mu \mathrm{g}$ of purified rat brain PKC was carried out under the standard assay conditions in the presence of $10 \mu \mathrm{l}$ of the purified PKC inhibitor (PKCI) $(0.2 \mu \mathrm{g} / \mu \mathrm{l})$. Where indicated, $40 \mathrm{mM} \mathrm{NaF}, 0.1 \mathrm{mM} \mathrm{L}$ serine, $1 \mathrm{mM}$ phenylmethylsulfonyl fluoride (PMSF) or $10 \mu \mathrm{g} / \mathrm{ml}$ leupeptin was included in the reaction mixture. $\mathrm{NaF}$ or L-serine was added as a phosphatase inhibitor, and PMSF or leupeptin as a protease inhibitor. Mean values of 3 to 5 experiments are shown.

These results suggest that the spermatozoan inhibitor does not act on PKC via proteolysis or phosphorylation processes.

These results altogether indicate that bovine spermatozoa contain a fairly potent $\mathrm{PKC}$ inhibitor which is a protein of approximately $63 \mathrm{kDa}$.

\section{Effect of the PKC Inhibitor and PKC on the Development of Fertilized Ova}

In order to demonstrate a possible function of the PKC inhibitor, its effect on the development of fertilized ova has been investigated. In this experiment, superovulation was induced by intraperitoneal injection of 5 units of PMSG, which was followed, $48 \mathrm{~h}$ later, by intraperitoneal injection of 5 units of HCG. Female mouse injected with PMSG and HCG was immediately housed together with a male mouse. Insemination has been known to occur $10 \mathrm{~h}$ after the HCG injection, and vaginal emboli resulted from the copulation has been taken as a possible sign of insemination. The two-cell stage in the development of fertilized ova can be divided into two phases, an early one (32-36 h postinsemination) and a late one (38-42 $\mathrm{h}$ post-insemination). Fertilized ova in the two-cell stage in vivo can pass the early and late phases smoothly and further proceed into the four-cell stage. In vitro, on the other hand, only two-cell late stage ova and not two-cell early stage ova can develop into the fourcell stage, because of the two-cell stage block (4). Fertilized ova were therefore taken out $10 \mathrm{~h}$ after 

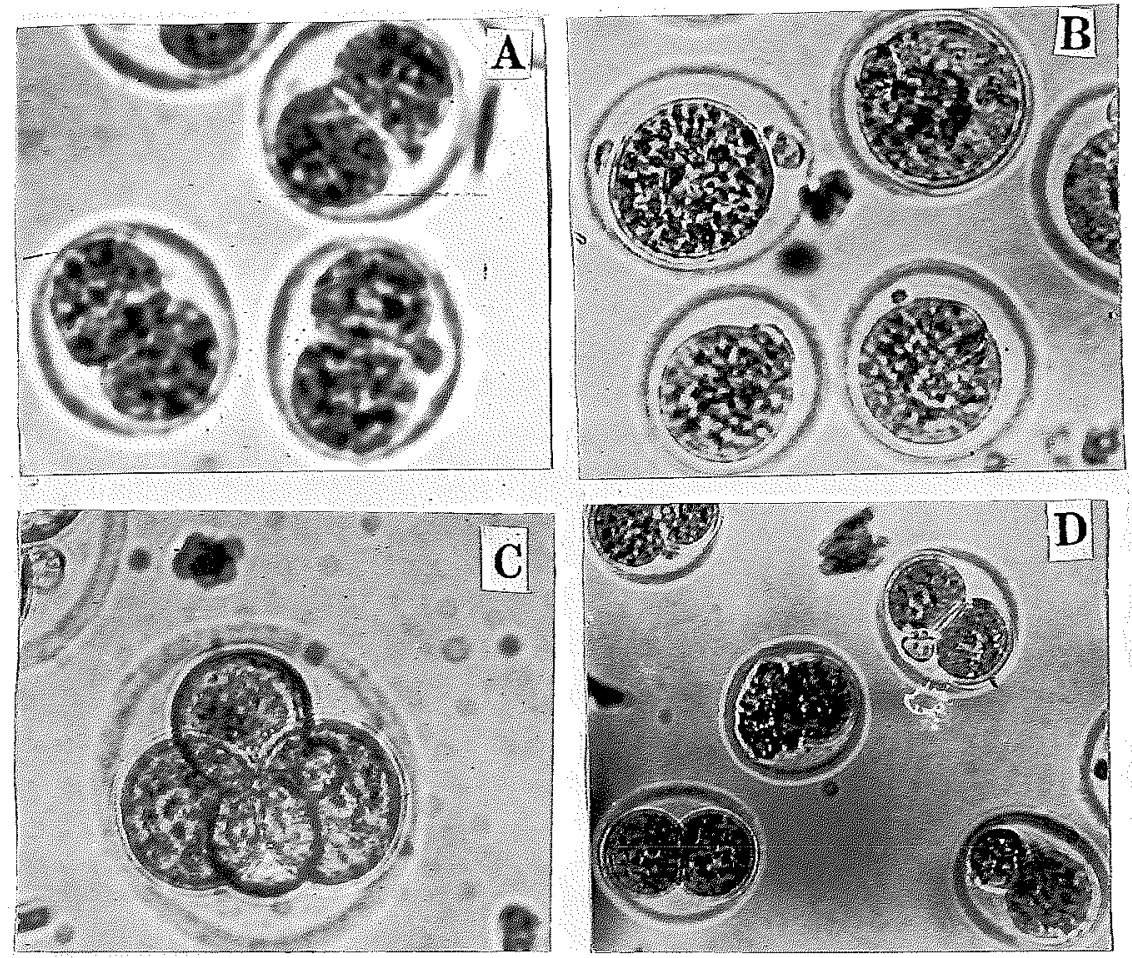

Fig. 6 Effect of the microinjected PKC inhibitor on the development of fertilized ova. Experimental procedures are as described in the text and under 'Materials and Methods'. A: Fertilized ova microinjected with 2 pl each of $0.9 \%$ $\mathrm{NaCl}$ as a control developed into two-cell stage ova $36 \mathrm{~h}$ after insemination. $\times 400$. B: Fertilized ova microinjected with $2 \mathrm{pl}$ each of the $\mathrm{PKC}$ inhibitor $(0.2 \mu \mathrm{g} / \mu \mathrm{l})$ failed to proceed to the two-cell stage. $\times 400$. C: Two-cell late stage ova microinjected with $2 \mathrm{pl}$ of $0.9 \% \mathrm{NaCl}$ as a control developed into four-cell stage ova $42 \mathrm{~h}$ after insemination. $\times 200$. D: Two-cell late stage ova microinjected with $2 \mathrm{pl}$ each of $0.2 \mathrm{mg} / \mathrm{ml} \mathrm{PKC}$ inhibitor remained in the two-cell stage. $\times 200$

insemination from the ovary of mice which had vaginal emboli. Two-cell stage ova of early and late phases were taken out from the oviduct $36 \mathrm{~h}$ and $42 \mathrm{~h}$ after insemination, respectively. Fertilized ova and two-cell late stage ova were microinjected with $2 \mathrm{pl}$ of the purified PKC inhibitor protein $(0.2 \mu \mathrm{g} /$ $\mu 1)$. Two-cell early stage ova were microinjected with $2 \mathrm{pl}$ of purified rat brain $\operatorname{PKC}(0.4 \mu \mathrm{g} / \mu 1)$. As a control, fertilized ova and two-cell early and late stage ova were microinjected with $2 \mathrm{pl}$ of $0.9 \%$ $\mathrm{NaCl}$. All these ova were then subjected to culture in the Whitten culture medium at $37^{\circ} \mathrm{C}$ for $26-$ $32 \mathrm{~h}$.

When the PKC inhibitor protein was microinjected, fertilized ova failed to develop into the twocell stage, and two-cell late stage ova failed to develop into the four-cell stage. In the control group, fertilized ova developed into two-cell stage ova $36 \mathrm{~h}$ after insemination, and two-cell late stage ova proceeded into the four-cell stage $42 \mathrm{~h}$ after insemination (Fig. 6). Fertilized ova microinjected with $2 \mathrm{pl}$ of boiled PKC inhibitor also developed into twocell stage ova.

As shown in Fig. 7, two-cell early stage ova microinjected with PKC developed into the fourcell stage and further into the eight-cell stage, whereas the control ova microinjected with $0.9 \%$ $\mathrm{NaCl}$ stayed in the two-cell stage because of the two-cell stage block.

\section{DISCUSSION}

It is well known that $\mathrm{Ca}^{2+}$ plays an important role in cell proliferation. A transient increase in intracellular $\mathrm{Ca}^{2+}$ concentration is a prerequisite for the development of fertilized ova (29). Outflow of $\mathrm{H}^{+}$ 


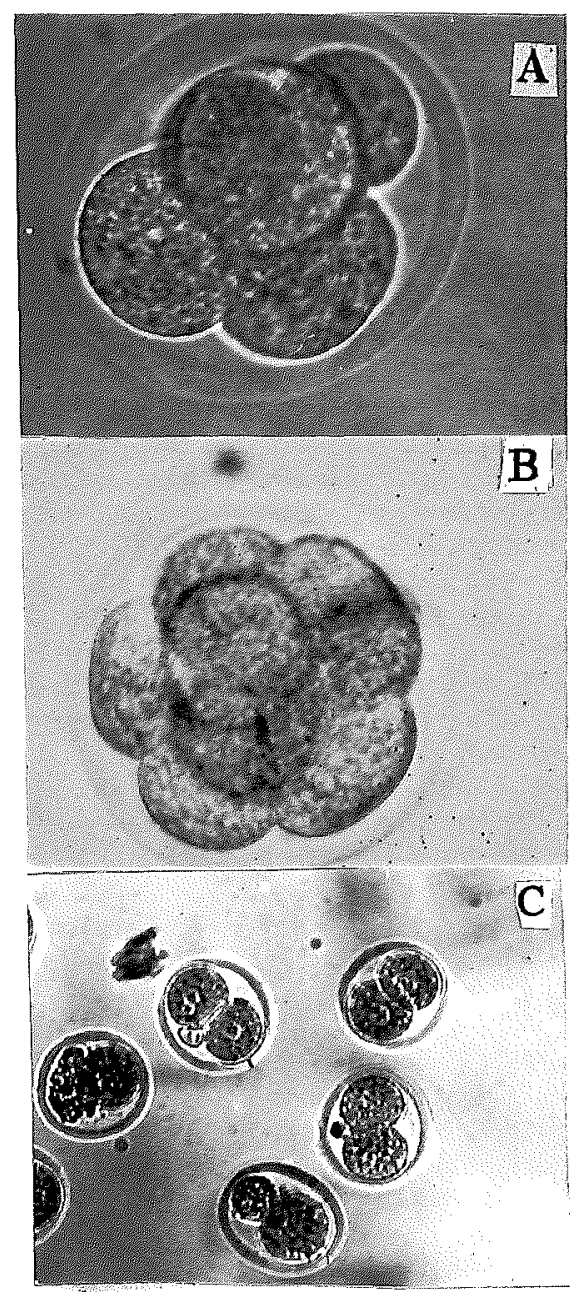

Fig.7 Effect of microinjected PKC on the development of two-cell early stage ova. Experimental procedures are as described in the text and under 'Materials and Methods'. Two-cell early stage ovum microinjected with $2 \mathrm{pl}$ of purified rat brain $\mathrm{PKC}(0.4 \mu \mathrm{g} / \mu \mathrm{l})$ developed into four-cell stage ovum $42 \mathrm{~h}$ after insemination $(\mathrm{A} ; \times 400)$, and further into the eight-cell stage on longer culture in the Whitten culture medium $(\mathrm{B} ; \times 200)$. Two-cell early stage ova microinjected with $2 \mathrm{pl}$ each of $0.9 \% \mathrm{NaCl}(\mathrm{C}$; $\times 100$ ) remained in the two-cell stage under the same culture conditions.

from cells has been observed in developing fertilized ova, resulting in an increase in intracellular $\mathrm{pH}$ from 6.6 to 7.2 , which is also a prerequisite for the development (13). The mechanism of the increment in intracellular $\mathrm{Ca}^{2+}$ concentration has been a target of current studies. Chapron et al. (2) suggested that epidermal growth factor opens $\mathrm{Ca}^{2+}$ channel and induces $\mathrm{Ca}^{2+}$ entry into cells. It has been also observed that microinjection of $\mathrm{Ca}^{2+}$ or inositol-1,4,5-trisphosphate $\left(\mathrm{IP}_{3}\right)$ promotes the development of fertilized ova, suggesting that the $\mathrm{IP}_{3}$ induced $\mathrm{Ca}^{2+}$ release from endoplasmic reticulum is involved in the increase in intracellular $\mathrm{Ca}^{2+} \mathrm{con}$ centration. Then how does $\mathrm{Ca}^{2+}$ function in ova? It is possible that $\mathrm{Ca}^{2+}$ acts through binding with calmodulin, a $\mathrm{Ca}^{2+}$-binding regulatory protein known to be abundant in ova. Another possibility is that $\mathrm{Ca}^{2+}$ acts through activation of PKC; both a certain concentration of $\mathrm{Ca}^{2+}$ and diacylglycerol are required in the activation of classical PKCs $(\alpha, \beta \mathrm{I}, \beta \mathrm{II}$ and $\gamma)(24,25)$. cDNA cloning analysis of different $\mathrm{PKC}$ isozymes showed that the classical PKCs have four conserved $\left(C_{1}\right.$ to $\left.C_{4}\right)$ and five variable $\left(V_{1}\right.$ to $V_{5}$ ) regions. The $C_{1}$ region is a putative membranebinding domain. The $\mathrm{C}_{2}$ region appears to be related to the $\mathrm{Ca}^{2+}$ requirement of the enzyme (25). When activated by an increase in intracellular $\mathrm{Ca}^{2+}$ concentration, $\mathrm{PKC}$ is known to associate with cell membrane. One of the known functions of $\mathrm{PKC}$ is the activation by phosphorylation of a $\mathrm{Na}^{+} / \mathrm{H}^{+}$ exchange protein. As a result of this activation, $\mathrm{H}^{+}$ is released from cells resulting in an increase in intracellular $\mathrm{pH}$ which is advantageous to cell division (34). Available evidence has also indicated that activated PKC regulates gene expression through acting on some transcriptional factors, such as CREB, AP-1 and I- $x \mathrm{~B}$, directly or indirectly (14).

PKC does exist in spermatozoa, but it has been difficult to measure its activity $(30,31)$. This may have been due, at least in part, to the presence of an inhibitor of PKC in spermatozoa. We have shown for the first time the presence of a $63 \mathrm{kDa} P K C$ inhibitor in bovine spermatozoa and purified it through Sephadex G-200 gel filtration chromatography, isoelectric focusing and Mono $Q$ column chromatography. Its inhibitory activity is fairly potent; inhibition observed with $2 \mu \mathrm{g}$ of the purified inhibitor is comparable with that with $5 \mu \mathrm{mol}$ of chlorpromazine. The inhibitor is neither phosphatase nor protease. We found recently that when bovine spermatozoa homogenate was incubated at pH 7.5 and $37^{\circ} \mathrm{C}$, approximately $50 \%$ and $60 \%$ of the PKC inhibitor activity were lost after the incubation for $12-16 \mathrm{~h}$ and $20 \mathrm{~h}$ respectively, suggesting that the inhibitor was inactivated by some protease(s) in spermatozoa. The nature of this proteolytic inactivation remains to be elucidated.

In the present study, the microinjected spermatozoa PKC inhibitor clearly inhibited the development of fertilized ova. This inhibition was observed in the development not only from one-cell stage 
ova to two-cell stage ova, but also from two-cell late stage ova to four-cell stage ova. In vitro, two-cell early stage ova can not proceed into the four-cell stage because of the two-cell stage block (4). However, microinjection of $2 \mathrm{pl}$ of purified rat brain PKC $(0.4 \mu \mathrm{g} / \mu \mathrm{l})$ allowed the two-cell early stage ova to develop into the four-cell and eight-cell stages, suggesting a promoting role of PKC in the development of fertilized ova. Recently, we detected immunohistochemically $\alpha, \beta$ and $\varepsilon$ isozymes of $\mathrm{PKC}$ in the bovine sperm tail and $\beta$ isozyme in the sperm head. The PKC inhibitor was also detected in the head of fresh bovine spermatozoa by an immunofluorescence method (Haihui Xue, Yu Yang, Zhihong Zong, Shengwu Wang and Bingzhi $\mathrm{Yu}$; to be published). A major interest related to these observations is whether or not the PKC in spermatozoa actually enters ova and promotes its development. Further studies along this line are in progress.

This study was supported in part by grant-in-aid for research on macromolecular inhibitor of PKC from the National Science Foundation of China.

\section{Received 2 February 1995; and accepted 6 April 1995}

\section{REFERENCES}

1. Balazovich K. J., Smolen J. E. and Boxer L. A. (1986) Endogenous inhibitor of protein kinase C: Association with human peripheral blood neutrophils but not with specific granule-deficient neutrophils or cytoplasts. $J$. Immunol. 137, 1665-1673

2. Chapron Y., Cochet C., Crozuy S., Jullien T., KeramiDAS M. and VeRDETTI J. (1989) Tyrosine protein kinase activity of the EGF receptor required to induce activation of receptor-operated calcium channels. Biochem. Biophys. Res. Commun. 158, 527-533

3. Charp P. A., Rice W. G., Raynor R. L., Reimund E., Kinkade J. M., Ganz T., Selsted M. E., Lehrer R. I. and Kuo J. F. (1988) Inhibition of protein kinase C by defensins, antibiotic peptides from human neutrophils. Biochem. Pharmacol. 37, 951-956

4. Flach G., Johnson M. H., Braude P. R., Taylor R. A. and Bolton V. N. (1982) The transition from maternal to embryonic control in the 2-cell mouse embryo. EMBO J.1, 681-686

5. Hannun Y. A. and Bell R. M. (1988) Aminoacridines, potent inhibitors of protein kinase C. J. Biol. Chem. 263, 5124-5131

6. Hannun Y. A., Loomis C. R., Merrill A. H. and Bell R. M. (1986) Sphigosine inhibition of protein kinase C activity and of phorbol dibutyrate binding in vitro and in human platelets. J. Biol. Chem. 261, 12604-12609

7. Hassell T. C., Magnino P. E. and Masaracchia R. A. (1988) Synthetic peptides derived from the nonmuscle myosin light chains are highly specific substrates for protein kinase C. Biochem. Biophys. Acta 957, 1-10
8. Hidaka H., Inagaki M., Kawamoto S. and Sasaki Y. (1984) Isoquinolinesulfonamides, novel and potent inhibitors of cyclic nucleotide-dependent protein kinase and protein kinase C. Biochemistry 23, 5036-5041

9. House C. and Kemp B. F. (1989) Protein kinase C contains a pseudosubstrate prototype in its regulatory domain. $\mathrm{Sci}$ ence 238, 1726-1728

10. House C., Wettenhall R. E. H. and Kemp B. E. (1987) The influence of basic residues on the substrate specificity of protein kinase C. J. Biol. Chem. 262, 772-777

11. Hucho F., Krliger H., Pribilla I. and Oberdieck U. (1987) A $40 \mathrm{kD}$ inhibitor of protein kinase C purified from bovine brain. FEBS Lett. 211, 207-210

12. Inoue M., Kishimoto A., Takai Y., Nishizuka Y., House C. and KeMP B. E. (1977) Studies on a cyclic nucleotideindependent protein kinase and its proenzyme in mammalian tissues. J. Biol. Chem. 252, 7610-7616

13. JoHNSON J. D. and EPEL D. (1976) Intracellular pH and activation of sea urchin eggs after fertilisation. Nature 262, 661-664

14. KaRIN M. and SMEAL T. (1992) Control of transcription factors by signal transduction pathways: the beginning of the end. TIBS 17, 418-422

15. Kikgawa U., Minakuchi R., Takai Y. and Nishizuka Y. (1983) Calcium-activated, phospholipid-dependent protein kinase (protein kinase C) from rat brain. Meth. Enzymol. 99, 288-298

16. Loomis C. R. and Bell R. M. (1988) Sangivamycin, a nucleoside analogue, is a potent inhibitor of protein kinase $C$. J. Biol. Chem. 263, 1682-1692

17. Lowry O. H., Rosebrough N. J., Farr A. L. and Randall R. J. (1951) Protein measurement with the folin phenol reagent. J. Biol. Chem. 193, 265-275

18. McDonald J. R. and Walsh M. P. (1985) Inhibition of the $\mathrm{Ca}^{2+}$ and phospholipid-dependent protein kinase by a novel MW 17,000 $\mathrm{Ca}^{2+}$-binding protein. Biochem. Biophys. Res. Commun. 129, 603-610

19. Miyazaki S., Yuzaki M., NaKada K., Shirakawa H., NaKanishi S., NaKade S. and Mikoshiba K. (1992) Block of $\mathrm{Ca}^{2+}$ wave and $\mathrm{Ca}^{2+}$ oscillation by antibody to the inositol 1,4,5-trisphosphate receptor on fertilized hamster eggs. Science 257, 251-255

20. Mori T., Takai Y., Minakuchi R., Yu B. and Nishizuka Y. (1980) Inhibitory action of chlorpromazine, dibucaine, and other phospholipid-interacting drugs on calcium-activated, phospholipids-dependent protein kinase. J. Biol. Chem. 255, 8378-8380

21. NishizuKa Y. (1984) The role of protein kinase C in cell surface signal transduction and tumor promotion, Nature 308, 693-698

22. NishizuKA Y. (1986) Studies and perspectives of protein kinase C. Science 233, 305-312

23. Nishizuka Y. (1988) The molecular heterogeneity of protein kinase $\mathrm{C}$ and its implications for cellular regulation. Nature 334, 661-665

24. NishizuKa Y. (1989) The family of protein kinase $\mathrm{C}$ for signal transduction. J. Amer: Med. Association 262, 1826-1833

25. NishizuKa Y. (1992) Intracellular signaling by hydrolysis of phospholipids and activation of protein kinase C. Science 258, 607-614

26. O'Brian C. A., Liskamp R. M., Solmon D. H. and WeIUSTERIN I. B. (1985) Inhibition of protein kinase $C$ by tamoxifen. Cancer Res. 45, 2462-2465

27. Ohta H., Tanaka T. and Hidaka H. (1988) Putative bind- 
ing site(s) of 1-(5-isoquinolinesulfonyl)-2-methyl-piperazine (H-7) on protein kinase C. Biochem. Pharmacol. 37, 2704-2706

28. Patel J. and Kassis S. (1987) Concanavalin A prevents phorbol-mediated redistribution of protein kinase $\mathrm{C}$ and adrenergic receptors in rat glioma $\mathrm{C}_{6}$ cells. Biochem. Biophys. Res. Commun. 144, 1265-1272

29. Ridgway E. B., Gilkey J. and JafFe L. F. (1977) Free calcium increases explosively in activating medaka eggs. Proc. Natl. Acad. Sci. USA 74, 623-627

30. Roldan E. R. S. and Harrison R. A. P. (1988) Absence of active protein kinase $\mathrm{C}$ in ram spermatozoa. Biochem. Biophys. Res. Commun. 155, 901-906

31. Rotem R., Paz G. F., Homonnai Z. T., Kalina M. and NAOR Z. (1990) Protein kinase $C$ is persent in human sperm: possible role in flagellar motility. Proc. Natl. Acad. Sci. USA 87, 7305-7308

32. Schatzman R. C., Wise B. C. and Fuo J. F. (1981) Phospholipid-sensitive calcium-dependent protein kinase: inhibition by antipsychotic drugs. Biochem. Biophys. Res. Commun. 98, 669-676

33. Schwantke N. and Le Peuch C. J. (1984) A protein kinase $\mathrm{C}$ inhibitory activity is present in rat brain homogenate. FEBS Lett. 177, 36-40
34. Siffert W. and Alzkerman J. W. N. (1988) Protein kinase $\mathrm{C}$ enhances $\mathrm{Ca}^{2+}$ mobilization in human platelets by activation of $\mathrm{Na}^{+} / \mathrm{H}^{+}$exchange. J. Biol. Chem. 263, 4223-4227

35. Su H. D., Kemp B. E., Turner R. S. and Kuo J. F. (1986) Synthetic myelin basic protein peptide analogs are specific inhibitors of phospholipid/calcium-dependent protein kinase (protein kinase C). Biochem. Biophys. Res. Commun. $134,78-84$

36. Vegesna R. V. K., Wu H. L., Mong S. and Crooke S. T. (1988) Staurosporine inhibits protein kinase $C$ and prevents phorbol ester-mediated leukotriene $D_{4}$ receptor desensitization in RBL-1 cells. Mol. Pharmacol. 33, 537542

37. Wise B. C., Schatzman R. C., Turner R. S., Kibler R. F, Kuo J. F., Glass D. B., Chou C. H. J., Rayhor R. L. and Катон N. (1982) Phospholipid-sensitive $\mathrm{Ca}^{2+}$-dependent protein kinase from heart. J. Biol. Chem. 257, 8489-8495

38. Wolf M. and BAGGiolini M. (1988) The protein kinase inhibitor staurosporine, like phorbol esters, induces the association of protein kinase $\mathrm{C}$ with membranes. Biochem. Biophys. Res. Commun. 154, 1273-1279

39. Yu A., Hou W., Zhang Y. and Yu B. (1989) Mechanism of $\mathrm{PKC}$ activation and possible action of $\mathrm{PKC}$ in cellular regulation. J. China Med. Univ. 18, 244-246 